\title{
TERAPI KELOMPOK SUPORTIF ASERTIF MENURUNKAN NILAI PERILAKU KEKERASAN PASIEN SKIZOFRENIA BERDASARKAN MODEL KEPERAWATAN INTERAKSI KING
}

\author{
Khamida \\ (UNUSA, FIK, Prodi SI Keperawatan, J1. Smea No 57 Surabaya) \\ JL.SMEA 57 Surabaya \\ Email: khamida2yd@gmail.com/ khamida@unusa.ac.id
}

\begin{abstract}
Introduction: Violent behavior can endanger ourselves, others and environment. One of the more optimal treatments which is highly needed is the assertive supportive group therapy by using the approach of King's model of nursing interaction, in which the patient together with his group is asked to give support to do the assertive behavior to each other. The study was purposed to analyze the effects of assertive supportive group therapy on violent behavior done by the Schizophrenic patients based on the King's interaction nursing model. Method: The design of this study was the pre-post test control group. The population involved the patients with violent behavior hospitalized in the in-patient ward of RSJ Menur Surabaya. The samples of 20 respondents were taken by using simple random sampling technique. The independent variable was the assertive supportive group therapy, whereas the dependent one was violent behavior. Furthermore, the data were collected by filling out the observation sheet. The data were processed by using Paired T-test, Wilcoxon's Signed Rank Test, and Mann-Whitney's statistic test. Result: The result of study showed that before receiving this therapy, the average value of violent behavior in the treatment group was 96.1, whereas the average value found in the control group was 75.1. After receiving the assertive supportive group therapy, the average value of violent behavior in the treatment group was 58.4, whereas the average value found in the control group was 54.8. Moreover, the result of statistic test in the treatment group showed that the value difference of violent behavior before and after the treatment was $p=0.005$, whereas the value difference found in the control group was $p=0.000$, and the effects of the assertive supportive group therapy on violent behavior was $p=0.045$. Discussion: The assertive supportive group therapy with King's model of nursing interaction could decrease the patient's violent behavior by optimizing the personal system and interpersonally giving support to one another within the group. Therefore, the qualitative study is needed to complete the information about how the assertive supportive group therapy brings some effects to decrease violent behavior.
\end{abstract}

ABSTRAK : Perilaku kekerasan merupakan perilaku membahayakan baik pada diri sendiri, orang lain maupun lingkungan. Untuk itu dibutuhkan penanganan yang lebih optimal. Salah satunya dengan terapi kelompok suportif asertif dengan pendekatan model keperawatan Interaksi King yaitu mengajak pasien secara bersama-sama dengan kelompoknya saling memberikan dukungan berperilaku asertif. Penelitian ini bertujuan menganalisa pengaruh terapi kelompok suportif asertif terhadap perilaku kekerasan pada pasien skizofrenia berdasarkan model keperawatan interaksi King.

Desain penelitian ini pre-post test control group desain. Populasi penelitian adalah pasien dengan masalah perilaku kekerasan di ruang rawat inap RS Jiwa Menur Surabaya. Besar sampel 20 responden diambil secara simple random. Variabel bebas adalah terapi kelompok suportif asertif dan variabel tergantungnya perilaku kekerasan. Data dikumpulkan dengan mengisi lembar observasi. Pengolahan data menggunakan uji statistik Paired t Test, Wilcoxon Signed Ranks Test, dan Mann Whitney .

Hasil penelitian menunjukkan bahwa sebelum diberikan terapi kelompok suportif asertif, rerata nilai perilaku kekerasan kelompok perlakuan adalah 96,1, sedangkan pada kelompok 
kontrol adalah75,1. Setelah diberikan terapi kelompok suportif asertif, rerata nilai perilaku kekerasan kelompok perlakuan adalah 58,4, sedangkan kelompok kontrol 54,8. Hasil uji didapatkan pada kelompok perlakuan ada perbedaan nilai perilaku kekerasan sebelum dan sesudah diberikan terapi kelompok suportif asertif $(\mathrm{p}=0,005)$, dan pada kelompok kontrol ada perbedaan antara nilai perilaku kekerasan sebelum dan sesudah diberikan terapi $(p=0,000)$, serta ada pengaruh pemberian terapi kelompok suportif asertif terhadap perilaku kekerasan $(\mathrm{p}=0,045)$.

Terapi kelompok suportif asertif berdasarkan model keperawatan Interaksi King dapat menurunkan perilaku kekerasan pasien dengan cara mengoptimalkan system personal dan secara interpersonal saling memberikan dukungan dalam kelompok. Untuk itu diperlukan penelitian kualitatif untuk melengkapai informasi tentang sejauh man terapi kelompok supotif asertif berpengaruh menurunkan perilaku kekerasan

\section{Kata kunci: Terapi kelompok suportif asertif, perilaku kekerasan, Skizofrenia}

\section{PENDAHULUAN}

Kesehatan jiwa adalah suatu kondisi sehat emosional, psikologis, dan sosial yang terlihat dari hubungan interpersonal yang memuaskan, perilaku dan koping yang efektif, konsep diri yang positif, dan kestabilan emosi (Videbeck, S.L, 2008). Menurut Towsend (2009) kesehatan jiwa merupakan kemampuan beradaptasi terhadap stressor, baik dari diri sendiri maupun lingkungan, berdasarkan kondisi yang nyata dan logika, perasaan dan perilaku yang sesuai dengan norma dan budaya setempat. Kesehatan jiwa merupakan kondisi emosional, psikologis dan sosial yang sehat serta mampu beradaptasi dari stresor yang ditandai dengan perilaku, koping dan emosi yang adaptif. Jika seseorang tidak berhasil beradaptasi dan koping tidak adaptif serta bersikap negatif terhadap diri sendiri dan orang lain dapat mengakibatkan gangguan jiwa.

Skizofrenia merupakan salah satu gangguan jiwa yang paling banyak ditemukan. Skizofrenia merupakan sekumpulan sindroma klinik yang ditandai dengan perubahan kognitif, emosi, persepsi dan aspek lain dari perilaku (Kaplan dan Saddock, 2005). Perubahan perilaku merupakan salah satu gejala yang dijumpai pada skizofrenia. Perilaku kekerasan merupakan tindakan atau perilaku yang membahayakan baik pada diri sendiri, orang lain maupun lingkungan. Menurut Stuart dan Laraia (2005), perilaku kekerasan merupakan salah satu respon terhadap stressor yang dihadapi oleh seseorang, yang ditunjukkan dengan perilaku kekerasan baik pada diri sendiri, orang lain maupun lingkungan, secara verbal maupun nonverbal. Data Rumah Sakit Jiwa Menur Surabaya tahun 2012, rata - rata terdapat 152 pasien skizofrenia perbulan dan masalah keperawatan perilaku kekerasan sebesar $40 \%$, yang merupakan masalah keperawatan terbesar kedua setelah halusinasi. Tindakan keperawatan pada pasien dengan perilaku kekerasan lebih berfokus pada pengendalian perilaku kekerasan secara eksternal, yaitu pengikatan fisik (restrain) dan pembatasan gerak (isolasi) serta tindakan kolaborasi dengan dokter dalam pemberian obat antipsikotik. Namun seringkali setelah diberi intervensi, pasien melakukan perilaku kekerasan ulang ketika sudah berkumpul kembali dengan teman-temannya, tiga pasien perilaku kekerasan yang sudah dilakukan perawatan atau penanganan maka dua diantaranya akan terjadi perilaku kekerasan ulang

Terjadinya perilaku kekerasan dipengaruhi oleh dua faktor, yaitu faktor predisposisi dan faktor presipitasi. Faktor predisposisi penyebab perilaku kekerasan dikaitkan dengan faktor psikologis, sosial budaya dan biologis. Menurut Wahyuningsih, D (2009) faktor psikologis yang dapat mempengaruhi terjadinya perilaku kekerasan adalah kehilangan, kegagalan yang berakibat frustasi, penguatan dan dukungan terhadap perilaku kekerasan, dan riwayat perilaku kekerasan. Sedangkan faktor presipitasi yang dapat menecetuskan terjadinya perilaku kekerasan ada dua, yaitu internal dan eksternal. Yang termasuk faktor internal 
klien diantaranya: kelemahan fisik, keputusasaan, ketidakberdayaan, dan kurang percaya diri. Sedangkan keributan, kehilangan obyek atau orang yang berharga dan adanya konflik interaksi sosial merupakan faktor eksternal atau lingkungan yang dapat mencetuskan terjadinya perilaku kekerasan. Situasi lingkungan atau kejadian eksternal dapat diinterprestasikan oleh pasien sebagai suatu ancaman, yang menyebabkan pasien berperilaku agresif atau perilaku kekerasan.

Perilaku kekerasan yang terjadi pada pasien perlu penanganan secara tepat, agar tidak terjadi sesuatu yang tidak kita inginkan, karena pasien dengan perilaku kekerasan dapat membahayakan diri pasien itu sendiri, orang lain, maupun lingkungan sekitar, misalnya bunuh diri atau membunuh orang lain. Untuk itu selain penaganan pengendalian perilaku dari diri pasien sendiri dengan latihan asertif, juga harus mempertimbangkan lingkungan untuk semua pasien ketika mencoba mengurangi, mengendalikan atau menghilangkan perilaku kekerasan pasien. Salah satu upaya yang bisa dilakukan adalah terapi suportif asertif. Terapi ini merupakan penggabungan antara terapi suportif dan latihan asertif, dimana pasien diajak secara bersama-sama dengan kelompoknya untuk saling memberikan dukungan berperilaku asertif, sehingga terbentuk suatu situasi terkondisi, dan dukungan dalam kelompok. Terapi ini dapat dilakukan perawat dengan menggunakan pendekatan model keperawatan Interaksi King. King mengemukakan bahwa manusia sebagai sistem terbuka yang berinteraksi dengan lingkungannya, dimana interaksi antara individu itu diharapkan mampu mengubah persepsi dan menghasilkan pemaknaan yang positif, sehingga memunculkan tindakan yang positif pula (Alligood, 2010). Menurut model keperawatan King, didalam sistem interaksi yang dinamis terdiri dari tiga sistem yang saling berinteraksi, yaitu sistem personal (individu), sistem interpersonal (kelompok) dan sistem sosial (Tomey \& Alligood, 2006).

Terapi kelompok suportif asertif dengan pendekatan model keperawatan interaksi King diberikan kepada pasien dengan menggunakan dua sistem yang saling berinteraksi yaitu sistem personal (individu) dan sistem interpersonal (kelompok). Sistem personal (individu) digunakan terutama pada sesi pertama dan kedua, sesi pertama diberikan untuk melatih cara-cara megendalikan perilaku kekerasan dan sesi kedua melatih bersikap asertif, dimana setelah diberikan sesi pertama dan kedua itu diharapkan pasien mempunyai persepsi dan gambaran diri yang positif sehingga dapat berperilaku asertif dalam menghadapi stressor. Untuk sistem interpersonal (kelompok) pada sesi ke tiga dan empat, yaitu mengajak pasien secara bersama-sama dengan kelompoknya untuk saling memberikan dukungan dalam berperilaku asertif sehingga pasien dapat lebih adaptif dalam menghadapi stressor.

\section{BAHAN DAN METODE}

Penelitian ini dirancang dengan penelitian ekperimental (pre-post test control group design), dengan tujuan untuk membuktikan pengaruh terapi kelompok suportif asertif terhadap perilaku kekerasan pasien skizofrenia berdasarkan model keperawatan interaksi King.

Populasi penelitian ini adalah pasien dengan masalah perilaku kekerasan di rawat inap Rumah Sakit Jiwa Menur Surabaya. Kriteria sampel : Usia 25 - 55 tahun, pasien sudah mendapatkan terapi generalis minimal Sp 1 ( membina hubungan saling percaya, identifikasi penyebab perasaan marah, tanda dan gejala yang dirasakan, perilaku kekerasan yang dilakukan, akibatnya serta cara mengontrol secara fisik 1 ), tidak ada penyakit fisik berat yang menyertai, pasien dapat berkomunikasi verbal , dan pasien dapat menulis dan membaca.

Besar sampel ditentukan dengan rumus hypothesis testing for two population means (two side test) dari sample size determination in health studies WHO soft-ware. hasil penelitian sebelumnya tentang Pengaruh Assertiveness Training (AT) terhadap Perilaku Kekerasan pada Klien Skizofrenia di RSUD Banyumas (Wahyuningsih,D 2009) diperoleh nilai $\sigma=4.14, \mu 1=8.83, \mu 2=$ 15.11. Jika dalam penelitian ini menggunakan $\alpha=5 \%$ dan $\beta=10 \%$, maka setelah dimasukkan soft ware diperoleh besar sampel 10. Dengan demikian, besar sampel dalam penelitian ini adalah 10 orang untuk 
setiap kelompok.

Variabel independen dalam penelitian ini adalah terapi kelompok suportif asertif. Variabel dependen dalam penelitian ini adalah perilaku kekerasan. Instrumen yang digunakan dalam variabel independen (pemberian terapi kelompok suportif asertif) menggunakan modul atau pedoman pelaksanaan terapi kelompok suportif asertif yang dimodifikasi sendiri oleh peneliti dengan mempertimbangkan kebutuhan data dalam penelitian ini. Instrumen perilaku kekerasan responden (variabel dependen) diobservasi dengan menggunakan skala pengukuran perilaku kekerasan dari Keliat (2003) yang yang merupakan hasil adopsi dari Morison (1994) dengan uji validitas pearson product moment dengan hasil $\mathrm{r}=$ 0.75 yang artinya valid untuk digunakan (lebih besar dari 0.30), untuk uji reliabilitasnya dengan menggunakan teknik Alfa Cronbach dengan hasil 0.90 (Keliat, 2003).

Penelitian ini dilakukan dengan rekomendasi dari program studi Magister keperawatan Fakultas keperawatan Unair dan ijin dari direktur Rumah Sakit Jiwa Menur Surabaya. Tahapan dalam pengumpulan data yang telah dilakukan peneliti adalah:.(1). Melakukan koordinasi RS Jiwa Menur Surabaya untuk pembentukan tim observer. (2) Sosialisasi pelaksanaan penelitian dan instrumen penelitian kepada perawat ruangan dan tim observer. Observer bertugas melakukan penilaian terhadap perilaku kekerasan responden pada saat pre test dan post test. Persamaan persepsi antara peneliti dan observer dilakukan dengan sosialisasi tentang insrumen penelitian yang digunakan untuk mengukur respon perilaku kekerasan dengan lembar observasi. Peneliti menjelaskan isi dan cara pengisian lembar observasi untuk pre test dan post test. (3) Seleksi pasien perilaku kekerasan yang akan dijadikan responden. Seleksi ini dilakukan oleh tim observer di ruang Wijaya Kusuma, jika memenuhi kriteria sampel maka dijadikan responden, selanjutnya dilakukan pre test selama 3 hari $(3 \times 24$ jam atau 3 shift perhari), jika responden belum 3 hari sudah dipindah ke ruang Gelatik atau Kenari maka pre test dilanjutkan oleh tim observer di ruang Gelatik atau Kenari, akan tetapi jika responden dipindah diruang selain Gelatik atau Kenari, maka responden tersebut di droup out atau dikeluarkan dari sampel. (4) Responden yang telah ditentukan berdasarkan kriteria sampel dibagi menjadi 2 kelompok yaitu sebagai kelompok perlakuan dan kelompok kontrol, dengan cara; responden yang dipindah diruang Gelatik dijadikan kelompok perlakuan dan responden yang dipindah di ruang Kenari dijadikan kelompok Kontrol.

Intervensi dilaksanakan selama 2 minggu, yaitu: tiga hari pertama dilaksanakan Pre test (3 shift perhari) oleh tim observer, hari ke empat sampai ke sembilan dilaksanakan Terapi kelompok suportif asertif selama 4 sesi untuk kelompok perlakuan, dengan rincian: hari ke empat dilaksanakan sesi pertama (melatih pasien cara-cara mengatasi perilaku kekerasan. Hari ke lima dilaksanakan sesi kedua (melatih berperilaku asertif). Hari ke tujuh dilaksanakan sesi ketiga (melatih pasien menggunakan sistem dukungan kelompok (support system) dalam mengendalikan perilaku kekerasan). Hari ke sembilan dilaksanakan sesi keempat ( evaluasi). Untuk kelompok kontrol tidak diberi terapi kelompok suportif asertif, hanya diberi tindakan medis dan perawatan rutin harian sesuai protap rumah sakit (terapi generalis). Dan kedua kelompok pada hari ke 10 sampai dengan 12 dilakukan post test ( 3 x 24 jam) oleh tim observer yang jaga pada setiap shift (shift pagi, sore dan malam).

\section{HASIL}

Tabel 1 Distribusi Responden Berdasarkan Karakteristik Responden di RS. Jiwa Menur Surabaya, bulan Mei 2013

\begin{tabular}{lcccc}
\hline \multirow{2}{*}{ Karakteristik } & \multicolumn{2}{c}{ Kelompok Perlakuan } & \multicolumn{2}{c}{ Kelompok Kontrol } \\
\cline { 2 - 5 } & Jumlah & Persentase(\%) & Jumlah & Persentase(\%) \\
\hline $\begin{array}{l}\text { 1. Umur } \\
\text { a. } 25-30 \text { tahun }\end{array}$ & 5 & 50 & 2 & 20 \\
\hline
\end{tabular}




\begin{tabular}{lcccc}
\hline b. 31-55 tahun & 5 & 50 & 8 & 80 \\
\hline $\begin{array}{l}\text { 2. Jenis Kelamin } \\
\text { a. Laki-Laki }\end{array}$ & 10 & 100 & 10 & 100 \\
\hline 3. Pendidikan & & & & \\
a. Tidak Sekolah & 0 & 0 & 1 & 10 \\
b. Dasar & 6 & 60 & 6 & 60 \\
c. Menengah & 4 & 40 & 2 & 20 \\
d. Tinggi & 0 & 0 & 1 & 10 \\
\hline 4. Riwayat Pekerjaan & & & & \\
a. Bekerja & 0 & 0 & 2 & 20 \\
b. Tidak Bekerja & 10 & 100 & 8 & 80 \\
\hline 5. Status perkawinan & & & & \\
a. Tidak Kawin & 9 & 90 & 5 & 50 \\
b. Kawin & 0 & 0 & 4 & 40 \\
c. Duda & 1 & 10 & 1 & 10 \\
\hline 6. Agama & & & & \\
a. Islam & 10 & 100 & 100 & 100 \\
\hline 7. Riwayat Perilaku Kekerasan & & & & \\
a. Pernah & 9 & 90 & 7 & 70 \\
b. Tidak Pernah & 1 & 10 & 3 & 30 \\
\hline 8. Frekuensi dirawat & & & & \\
a. 1 -5 kali & 7 & 70 & 9 & 90 \\
b. 6-10 kali & 0 & 0 & 1 & 10 \\
c. >10 kali & 3 & 30 & 0 & 0 \\
\hline 9. Diagnosa Medis & & & \\
a. Skizofrenia Paranoid & 1 & 10 & 1 & 10 \\
b. Selain Skizofrenia Paranoid & 9 & 90 & 9 & 90 \\
\hline
\end{tabular}

Tabel 2. Distribusi Perilaku Kekerasan Responden Sebelum (Pre test) Diberikan Terapi di RS. Jiwa Menur Surabaya, Mei 2013

\begin{tabular}{|c|c|c|c|c|c|c|c|}
\hline \multirow{2}{*}{$\begin{array}{l}\text { Komponen } \\
\text { Kekerasan }\end{array}$} & \multicolumn{3}{|c|}{ Perlakuan } & \multicolumn{3}{|c|}{ Kontrol } & \multirow{2}{*}{$\begin{array}{c}\mathrm{p} \\
\text { Mann } \\
\text { Whitney }\end{array}$} \\
\hline & Mean & Median & $\begin{array}{l}\text { Min - } \\
\text { Mak }\end{array}$ & Mean & Median & $\begin{array}{l}\text { Min - } \\
\text { Mak }\end{array}$ & \\
\hline Diri sendiri & 18,1 & 17,5 & $15-23$ & 17,3 & 16,5 & $15-27$ & \\
\hline Orang Lain & 19,3 & 18,5 & $14-30$ & 16,9 & 15 & $13-23$ & \\
\hline Lingkungan & 30 & 28 & $15-60$ & 19,3 & 18,5 & $15-31$ & \\
\hline Verbal & 28,7 & 28 & $19-48$ & 21,6 & 21,5 & $16-28$ & \\
\hline $\begin{array}{c}\text { Perilaku } \\
\text { Kekerasan }\end{array}$ & 96,1 & 94 & $66-153$ & 75,1 & 71 & $62-96$ & 0,017 \\
\hline
\end{tabular}

Tabel 3 Distribusi Perilaku Kekerasan Responden Sebelum (Pre test) dan Sesudah (Post test) Terapi di RS. Jiwa Menur Surabaya, Mei 2013

\begin{tabular}{|c|c|c|c|c|}
\hline Perilaku Kekerasan & $\mathrm{n}$ & Mean & SD & $\mathrm{p}$ \\
\hline \multicolumn{5}{|l|}{ Kelompok Perlakuan } \\
\hline Sebelum (Pre test) & 10 & 96,10 & 23,634 & \multirow[t]{2}{*}{$\begin{array}{c}\text { Wilcoxon Signed Ranks Test } \\
0,005\end{array}$} \\
\hline Sesudah (Post test) & 10 & 58,4 & 3,565 & \\
\hline \multicolumn{5}{|l|}{ Kelompok Kontrol } \\
\hline Sebelum (Pre test) & 10 & 75,10 & 11,902 & \multirow[t]{2}{*}{$\begin{array}{l}\text { Paired T Test } \\
\quad 0,000\end{array}$} \\
\hline Sesudah (Post test) & 10 & 54,9 & 0,876 & \\
\hline
\end{tabular}


Tabel 4 Distribusi Penurunan (selisih pre-post test) Perilaku Kekerasan Responden Sesudah Diberikan Terapi di RS. Jiwa Menur Surabaya, Mei 2013

\begin{tabular}{cccccc}
\hline Kelompok & Mean & Median & Min-Mak & SD & p Mann Whitney \\
\hline Perlakuan & 37,7 & 38,5 & $3-92$ & 23,376 & 0,045 \\
Kontrol & 20,2 & 17 & $6-41$ & 11,698 & 0,045 \\
\hline
\end{tabular}

\section{PEMBAHASAN.}

Hasil penelitian menunjukkan bahwa sebelum diberikan terapi kelompok suportif asertif kelompok perlakuan maupun kelompok kontrol mengalami perilaku kekerasan yang tidak terkendali dengan rerata nilai perilaku kekerasan kelompok perlakuan adalah 96,1 dan kelompok kontrol 75,1. Dan setelah diberikan terapi kelompok suportif asertif baik pada kelompok perlakuan maupun kelompok kontrol mengalami penurunan nilai perilaku kekerasan, namun pada kelompok perlakuan penurunan nilai perilaku kekerasan lebih besar dari pada kelompok kontrol, pada kelompok perlakuan rerata penurunan nilai sebesar 37,7, sedangkan kelompok kontrol sebesar 20,2. Hasil uji didapatkan pada kelompok perlakuan ada perbedaan nilai perilaku kekerasan sebelum dan sesudah diberikan terapi kelompok suportif asertif $(p=0,005)$, dan pada kelompok kontrol ada perbedaan antara nilai perilaku kekerasan sebelum dan sesudah diberikan terapi $(\mathrm{p}=0,000)$, serta ada pengaruh pemberian terapi kelompok suportif asertif terhadap perilaku kekerasan ( $\mathrm{p}=$ 0,045).

Terapi kelompok suportif asertif merupakan penggabungan antara terapi suportif dan latihan asertif . Terapi kelompok suportif asertif merupakan terapi yang diberikan kepada pasien secara bersama-sama dengan kelompoknya sesama pasien perilaku kekerasan untuk saling memberikan dukungan dalam berperilaku asertif. Hal ini sesuai dengan pendapat Hernawaty, dkk (2011) yang menyatakan bahwa terapi kelompok suportif merupakan terapi yang diberikan pada sekumpulan dua orang atau lebih yang memiliki anggota dengan cara mengklarifikasi permasalahan yang dihadapi pasien sehingga pasien mampu memanfaatkan support system yang dimilikinya dan mengekspresikan pikiran serta perasaannya melalui ekspresi verbal. Sedangkan Latihan asertif (Assertiveness Training) menurut Fortinash (2003) merupakan komponen dari terapi perilaku dan suatu proses dimana individu belajar mengkomunikasikan kebutuhan, menolak permintaan dan mengekspresikan perasaan positif dan negatif secara terbuka, jujur, langsung, dan sesuai dengan pemahaman. Individu yang menggunakan respon asertif mempertahankan haknya dan respek terhadap hak dan harkat orang lain.

Terapi kelompok suportif asertif yang diberikan pada pasien dalam penelitian ini menggunakan pendekatan model keperawatan Interaksi King, yaitu dengan menggunakan dua sistem yang saling berinteraksi yaitu sistem personal (individu) dan sistem interpersonal (kelompok). Hal ini sesuai dengan teori model keperawatan King yang diungkapkan oleh Tomey \& Alligood (2006) yang menyatakan bahwa didalam sistem interaksi yang dinamis terdiri dari tiga sistem yang saling berinteraksi, yaitu sistem personal (individu), sistem interpersonal (kelompok) dan sistem sosial. Dalam pelaksanaan terapi kelompok suportif asertif, sistem personal (individu) digunakan terutama pada sesi pertama dan kedua. Sesi pertama diberikan untuk melatih cara-cara mengendalikan perilaku kekerasan dan sesi kedua melatih bersikap asertif, dimana setelah diberikan sesi pertama dan kedua itu pasien mempunyai persepsi dan gambaran diri yang positif sehingga dapat berperilaku asertif dalam menghadapi stressor. Untuk sistem interpersonal (kelompok) pada sesi ke tiga dan empat, yaitu mengajak pasien secara bersama-sama dengan kelompoknya untuk saling memberikan dukungan dalam berperilaku asertif sehingga pasien dapat lebih adaptif dalam menghadapi stressor. Sedangkan pada system sosial tidak banyak diterapkan pada penelitian ini, karena responden masih dirumah sakit dan belum bias melibatkan keluarga pasien.

Terapi kelompok suportif asertif sesi pertama, yang dilakukan adalah mendiskusikan dengan pasien mengenai perilaku kekerasan, jenis perilaku kekerasan yang pernah dilakukan, akibat dan cara 
mengendalikan perilaku kekerasan, serta memotivasi pada pasien untuk mengungkapkan pendapat dan pikirannya tentang berbagai macam informasi yang diketahui, memberi umpan balik positif kepada pasien mengenai cara mengendalikan perilaku kekerasan yang sudah benar dilakukannya selama ini dan memberi masukan serta penjelasan mengenai perawatan pasien perilaku kekerasan yang belum diketahui atau belum dipahami. Hasil dari evaluasi pelaksanaan sesi pertama ini didapatkan bahwa seluruh pasien didapatkan melaksanakan sesi pertama dengan baik, meskipun ada 3 orang (30\%) pasien awalnya pasif dan kurang terbuka, tetapi setelah diberi motivasi dan melihat teman-temannya yang lain, maka menjadi lebih aktif dan terbuka. Berdasarkan hasil diskusi pada pelaksanaan sesi pertama ini ada beberapa cara mencegah atau mengendalikan perilaku kekerasan yang diungkapan oleh anggota kelompok terapi diantaranya mandi, berwudhu, sholat, berdzikir, mengaji atau membaca Alquran, menyanyi atau mendengarkan musik.

Terapi kelompok suportif asertif sesi kedua adalah melatih berperilaku asertif. Latihan asertif merupakan tindakan untuk melatih kemampuan dasar interpersonal yang sering teganggu pada klien skizofrenia (Stuart \& laraia, 2005), kemampuan yang dimaksud yaitu mengkomunikasikan secara langsung pada orang lain, mengatakan tidak untuk permintaan yang tidak rasional, menyampaikan rasa tidak setuju dan mengekspresikan pendapat. Berdasarkan evaluasi akhir pelaksanaan sesi kedua ini seluruh anggota dapat mendemontrasikan cara berperilaku asertif, misalnya meminta dan menolak dengan menggunakan bahasa baik atau asertif. Pada sesi kedua ini anggota kelompok dilatih untuk mengkomunikasikan secara langsung pada orang lain, mengatakan tidak untuk permintaan yang tidak rasional, menyampaikan rasa tidak setuju dan mengekspresikan pendapat, selain itu latihan asertif pada sesi ini dapat memotivasi pasien untuk lebih berperan aktif berkomunikasi yang lebih baik kepada orang lain, sehingga perilaku kekerasan secara verbal dapat dikendalikan. Hal ini sesuai dengan penelitian Yen-Ru Lin, et.al (2008) yang berjudul "Evaluation of assertiveness training for psychiatric patients" menyatakan bahwa segera dan setelah satu-bulan followup diberikan assertiveness training subjek mengalami peningkatan yang signifikan dalam sikap asertif. Wahyuningsih (2009) dalam penelitiannya yang berjudul "pengaruh assertiveness Training terhadap perilaku kekerasan pada klien skizofrenia" menyatakan bahwa terapi generalis dan Assertiveness Training terbukti menurunkan perilaku kekerasan pada klien Skizofrenia dan direkomendasikan.

Sesi ketiga dilaksanakan yaitu dengan melatih pasien menggunakan system dukungan kelompok (support system) dalam mengendalikan perilaku kekerasan. Sesi ini setiap pasien memiliki daftar kemampuan dalam menggunakan dukungan antar anggota kelompok, mampu melakukan demonstrasi atau role play cara menggunakan dukungan, misalnya saling mengingatkan antar anggota jika ada salah satu temannya mau atau sedang marah dengan tugas masing-masing yang tealah disepakati bersama oleh kelompok. Namun pada kenyataannya ada salah satu anggota meminta rokok dengan marah, maka teman atau anggota yang lain mengingatkan untuk meminta rokok dengan cara yang baik. Hal ini sesuai dengan model keperawatan interaksi King yang menyatakan bahwa interaksi antara individu itu diharapkan mampu mengubah persepsi dan menghasilkan pemaknaan yang positif, sehingga memunculkan tindakan yang positif pula.

Sesi keempat dilaksanakan untuk mengevaluasi pengalaman yang dipelajari berkaitan dengan penggunaan system dukungan baik dari diri pasien maupun dari luar. Sesi ini pasien menceritakan bahwa setiap kali berkeinginan marah langsung melaksanakan tindakan yang dinjurkan pada sesi pertama dan kedua, ada lima orang yang menyatakan dilakukan dengan bernyanyi, dua orang dengan mandi, dua orang berwudlu dan satu orang dengan berdzikir. Dan selain itu saling mengingatkan antar temannya agar marah tidak terjadi.

Dalam terapi kelompok suportif asertif pasien skizofrenia yang mengalami perilaku kekerasan mampu mengatasi atau mengendalikan perilaku kekerasannya, karena terbentuknya suatu situasi yang terkondisi, dukungan yang telah diciptakan dalam kelompok, karena hubungan yang 
bersifat suportif antar anggota yang dibangun, mampu membuat pasien mengendalikan perilaku kekerasannya dengan cara mengoptimalkan kemmapuan positif pada dirinya dan dukungan dari anggota kelompok

\section{SIMPULAN DAN SARAN}

\section{Simpulan}

Pasien dengan perilaku kekerasan pada kelompok perlakuan dan kelompok kontrol mengalami perilaku kekerasan yang tidak terkendali sebelum diberikan terapi kelompok suportif asertif dan kelompok perlakuan mengalami penurunan nilai perilaku kekerasan lebih besar dari pada kelompok kontrol setelah diberikan terapi kelompok suportif asertif. Terapi kelompok suportif asertif berdasarkan model keperawatan Interaksi King dapat menurunkan perilaku kekerasan pasien dengan cara mengoptimalkan system personal dan secara interpersonal saling memberikan dukungan dalam kelompok.

\section{Saran}

Diharapkan adanya pemberian terapi aktivitas kelompok suportif asertif sebagai upaya untuk membantu klien mengendalikan perilaku kekerasan. Dan perlu penelitian tentang terapi kelompok suportif asertif dengan melibatkan keluarga, sebagai persiapan perawatan pasien setelah keluar dari rumah sakit (di rumah). Serta penelitian kualitatif untuk melengkapai informasi tentang sejauh mana terapi kelompok supotif asertif berpengaruh menurunkan perilaku kekerasan,

\section{KEPUSTAKAAN}

Akihiro Shiina. 2005. An Open Trial of Outpatient group Therapy for Bulimic Disorder: Combination program of Cognitive Behavioral Therapy with Assertive Training and Self Esteem Enhancement.Psychiatry and Clinical Neurosciences, 59,690 -696

Arikunto, S. 2006. Prosedur Penelitian Suatu Pendekatan Praktek . Edisi Revisi VI Jakarta: Rineka Cipta

Alligood. 2010. Nursing Theory Utilization \& Application. Fourth edition. Philadelphia USA: Mosby
Chien, W.T., Chan, S.W.C dan Thompson, D.R . 2006. Effects of a mutual support group for families of chinese people with schizophrenia: 18-months followup. http://bjp.rcpsych.org, diperoleh tanggal 10 Februari 2013.

Citrome \& Volavka. 2002. Aggression retrievol. www.emedicine.com. Diakses tanggal 10 februari 2013.

Degleris,N, Mantelou.E, Solias.A, Karamberi. D and Milinie A. 2008 . Assertiveness training as major component element of a psychoeducational program addressed to psychiatric patients and their families.http://www.annals-generalpsychiatry.com/content/7/SI/S300. diakses tanggal 10 Januari 2013

Dharma Kelana K., 2011. Metodologi Penelitian Keperawatan : Panduan Melaksanakan dan Menerapkan Hasil Penelitian. Jakarta : Trans Info Media

Direja, AHS .2011. Buku Ajar Asuhan Keperawatan Jiwa. Yogyakarta. Nuha Medika.

Fakultas Ilmu Keperawatan Universitas Indonesia (FIK UI) .2011. Draf Standar Asuhan Keperawatan. Program pendidikan kekhususan keperawatan jiwa fakultas ilmu keperawatan Universitas Indonesia Depok.

Fontaine, K.L .2009., Mental health nursing. $5^{\text {th }}$ ed. New Jersey: Pearson Education, Inc.

Fortinash. 2003. Psychiatric mental health nursing. St. Louis: Mosby

Hayakawa,M.,2009. How repeated 15-minute assertiveness training sessions reduce wrist cutting in patients with borderline personality disorder. American Journal of psychotherapy. Vol 63, No.I.

Hijazi.M.A, Tavakoli.S, Slavin-Spenny.M.O, and Lumley.A.M. 2011. Targeting Interventions: Moderators of the effects of expressive writing and assertiveness training on the adjustment of international university students. Int J Adv Counselling:33:101-112

Hernawaty.T, Widiastuti.H.S, Hidayati E. 2011. Modul Modifikasi Terapi Kelompok Suportif pada Perilaku 
Kekerasan dengan Klien Skizoprenia. Program pendidikan kekhususan keperawatan jiwa fakultas ilmu keperawatan Universitas Indonesia Depok.

Isaacs, Ann. 2005. Panduan Belajar: Keperawatan Kesehatan Jiwa \& Psikiatrik. .ed. Indonesia. Ed.3. Jakarta: EGC

Kaplan \& Saddock. 2005. Comprehensive textbook of psychiatry. $8^{\text {th }}$ ed, Lippincot: Williams \& Wilkins.

Keliat, Budi A. 2003.Pemberdayaan Klien dan Keluarga dalam Perawatan Klien Skizofrenia dengan Perilaku Kekerasan di Rumah Sakit Jiwa Pusat Bogor. Disertasi. Universitas Indonesia

Keliat,B. A dan Akemat. 2005. Keperawatan Jiwa Terapi Aktivitas Kelompok. Jakarta: Penerbit buku kedokteran EGC

Kementrian Kesehatan. 2011. Kementrian Kesehatan Prioritaskan Kesehatan Jiwa .http://www.depkes.go.id . diperoleh tanggal 12 desember 2013.

Klingberg,et.al. 2010. Cognitive Behavioural Therapy Versus Supportive Therapy for Persistent Positive Symptoms in Psychotic Disoder: The Positive Study,a Multicenter,Prospective, Single-Blind,Randomised Controlled Clnical

Trial.http://www.trialsjournal.com/con tent/11/1/123. diakses tanggal 10 Januari 2013.

Maramis,W. F .2011. Catatan Ilmu Kedokteran Jiwa. Surabaya: Airlangga University Press.

Maleis, A. I. 2012. Theoritical Nursing : Development Progress. $5^{\text {th }}$ ed. Philadelphia: Lippincott

Nihayati, H.E. 2010. Pengaruh Terapi Kelompok Suportif terhadap Kemandirian Pasien Skizofrenia yang Mengalami Defisit Perawatan Diri di Rumah Sakit Jiwa Surabaya. Tesis.Universitas Airlangga. Tidak dipublikasikan

Potter dan Perry .2005. Buku Ajar Fundamental Keperawatan: Konsep, Proses dan Praktik, Edisi 4, Alih Bahasa oleh Yasmin Asih, Jakarta:EGC

Sell, Kallofissudis.2005. The Evolving
Essence of The Science of Nursing, A Complexity Integration Nursing Theory. http://www.nursing.gr. Diakses tanggal 20 November 2012

Stuart, G.W .2009. Principles and practice of psychiatric nursing, $.9^{\text {th }}$ ed. Missouri: Mosby, Inc

Stuart, G.W., and Laraia .2005., Principles and practice of psychiatric nursing $.7^{\text {th }}$ ed. St.Louis, Missouri: Mosby Year Book

Stuart \& Sundeen .2006., Keperawatan psikiatrik: Buku Saku Keperawatan Jiwa, Edisi 5. Jakarta: EGC

Sunardi .2010. Latihan Asertif. PLB FIB UPI. Makalah tidak dipublikasikan

Surtiningrum, A. 2011. Pengaruh terapi suportif terhadap kemampuan bersosialisasi pada klien isolasi sosial di rumah sakit jiwa daerah Dr.Amino Gondohutomo Semarang. Tesis. Universitas Indonesia.

Susana \& Hendarsih. 2012. Terapi Modalitas Keperawatan Kesehatan Jiwa. Jakarta : EGC

Tommey, A.M and M.R. Alligood. 2006. Nursing Theorists and Their Work. Philadelphia USA: Mosby

Townsend, M.C. 2009. Essentials of psychiatric mental health nursing $.3^{\text {rd }}$ ed. Philadelphia, F.A. Davis Company

Varcarolis, E., Carson, V.B., Shoemaker, N.C. 2006. Foundations of psychiatric mental health nursing. A clinical approach, $5^{\text {th }}$ ed, St.Louis: Elsevier.

Videbeck, Sheila L. 2008. Psychiatric mental health nursing. $3^{\text {rd }}$ edition. Philadhelpia: Lippincott Williams \& Wilkins

Wahyuningsih,D 2009. Pengaruh Assertiveness Training (AT) terhadap Perilaku Kekerasan pada Klien Skizofrenia di RSUD Banyumas. Tesis. Universitas Indonesia. Jakarta

Yen-Ru Lin, Mei-Hsuen Wu, Cheng-I Yang, Tsai-Hwei Chen, Chen-Chuan Hsu, Yue-Cune Chang, et.al. 2008. Evaluation of Assertiveness of Training for Psychiatric Patient. Journal of Clinical Nursing, 17,28752883

Yosep, I .2011.. Keperawatan Jiwa, Edisi revisi. Bandung: Refika Aditama 
